\title{
PERSONAL HYGIENE ANALYSIS, ENVIRONMENTAL SANITATION AND SKIN HEALTH COMPLAINTS IN INMATES AT CLASS IIA MEDAN WOMEN'S CORRECTIONAL INSTITUTION IN 2020
}

\author{
Dina Tania Gultom and Irna Marsaulina \\ Faculty of Public Health, Universitas Sumatera Utara, Indonesia \\ irnamarsaulina@yahoo.com
}

Keywords : Skin, hygiene, sanitation, correctional institution

\begin{abstract}
Analysis of Personal Hygiene, Environmental Sanitation and Skin Health Complaints in Inmates at The Class IIA Medan Women's Correctional Institution. This type of research is quantitative research that is descriptive survey. The research was conducted from September 2019 to September 2020 at the Medan Class IIA Women's Correctional Institution. Samples from this study were 86 people. However, personal hygiene of inmates belongs to the bad category with the highest proportion in terms of cleanliness of the use of beds and bed linen (50\%), but environmental sanitation conditions in the Medan Class IIA Women's Correctional Institution are included in the criteria of eligibility.
\end{abstract}

\section{INTRODUCTION}

Based on Indonesia Health Profile Data in 2009 explained that skin diseases and other subcutaneous tissues ranked third out of the ten highest number of diseases in hospitals in Indonesia in outpatients with the number of visits that is about 371,673 visits and a total of 247,256 cases (Ministry of Health, 2010).

According to Achmadi (2017), disease is an interactive result between human behavior or habits towards environmental components that have the potential of disease, this is known as the process of disease occurrence. According to Budiman and Suyono (2019), the way of transmission of skin diseases can be directly contacted or through equipment such as clothes, towels, bed linen, mats, pillows, and others. Several ways can be done to prevent this skin disease such as maintaining personal hygiene and maintaining environmental cleanliness. According to Isro'in and Andarmoyo (2012), personal hygiene is an act of maintaining one's hygiene and health for both physical and psychic well-being. According to Maharani (2015), one of the factors causing skin diseases is environmental sanitation. Environments with unhealthy and unguarded sanitation can affect the course of disease, the cause of disease and act as a medium of transmission of disease. Based on Law No. 23 of 1992 explained that the target of the implementation of environmental health one of them is a residential environment including residential, dormitory or the like (Sari, 2019).

Based on the Decree of the Minister of Justice and Human Rights of the Republic of Indonesia Number: M. 01. Pl. 01. 01. In 2003, the Prison Institute was a place to foster inmates and correctional students. Based on the Regulation of the Minister of Law and Human Rights of the Republic of Indonesia No. 11 of 2017, the state of prisons or correctional institutions has been overcrowded almost throughout Indonesia. Prisons or correctional institutions in Indonesia have an ideal capacity of about 119,860 people, but the number of Community Correctional Assistance (WBP) of 209,417 people, then there is an overcapacity of about $75 \%$. This results in limited sanitation facilities, so the residents of prisons or prisons are also limited in maintaining personal hygiene (individual hygiene). Thus, such circumstances can be at risk of transmission of the disease.

Medan Women's Correctional Institution Class IIA (LPP) provides 55 cell rooms consisting of 47 large rooms and 8 restrooms. Each large room is $5 \times 6$ 
$\mathrm{m} 2$ and the occupants of 15 inmates per room while each small room is $3 \times 4 \mathrm{~m} 2$ and the occupants of 3 inmates per room. Then it can be known that inmates' prisons are overcrowded. As in large rooms with a size of $5 \times 6 \mathrm{~m} 2$ and residents of 15 people, then each inmate has a residential density capacity of $2 \mathrm{~m} 2$ per person and this is not in accordance with the requirements based on the Decree of the Minister of Health of the Republic of Indonesia Number 829/Menkes/SK/VII/1999 which recommends a minimum room area of $8 \mathrm{~m}^{2}$ and not used $>2$ persons (4 $\mathrm{m} 2$ per person).

Several studies have been conducted in showing personal hygiene, environmental sanitation, and the incidence of skin diseases have a relationship, among others based on research conducted Frenki (2011) in Pesantren Darel Hikmah explained there is a personal hygiene relationship such as skin hygiene, hand and nail hygiene, genitalia hygiene, clothing hygiene, towel hygiene, bed hygiene and bed linen to the incidence of skin diseases. Similarly, based on research submitted by Agsa Sajida (2012) on The Relationship of Personal Hygiene and Environmental Sanitation with Complaints of Skin Diseases in The Village Denai District Denai Medan stated there is a meaningful relationship of skin hygiene, hand and nail hygiene, clothing hygiene, towel hygiene, cleanliness of beds and bed linen, cleanliness of environmental sanitation against complaints of skin diseases in the Village Denai Denai District Medan.

Preliminary survey of researchers at the Women's Correctional Institution Class IIA Medan, some inmates revealed that the water supply for inmates is smooth and adequate but the source of clean water provided for inmates using well water drills so that the water used by inmates looks a little murky. Lighting and ventilation are sufficient in each room but the conditions in the room feel humid. The supply of clothesline outside the room is very minimal resulting in inmates drying clothes at the front gate of the room. This inhibits natural lighting from entering the inmate's room.

According to a statement from some inmates at the Medan Class IIA Women's Correctional Institution, the humid conditions in the room triggered the development and growth of some insects and other small animals such as tomcats (seedling ants), mites, worms, centipedes, and others. The presence of some insects and other small animals is very disturbing and troubling for inmates and causes some inmates to complain of health problems on the skin such as itching, reddened skin in certain parts of the body even almost all parts of the body and skin undergo exfoliation and the surface of the skin bubbles filled with fluid. This is according to the Data Report from the Polyclinic
Women's Correctional Institution Class IIA Medan in 2020 lists the number of skin diseases in April 2020 to June 2020 included in the 3 most of several other diseases experienced by inmates and this will always be experienced by inmates with a considerable amount every month.

\section{RESEARCH METHODS}

This research used a quantitative methods for emphasize objective measurements and the statistical, mathematical, or numerical analysis of data collected through polls, questionnaires, and surveys, or by manipulating pre-existing statistical data using computational techniques. Quantitative research focuses on gathering numerical data and generalizing it across groups of people or to explain a particular phenomenon.

This research is a quantitative research that is descriptive survey with cross sectional approach that aims to provide or review a broad picture of the phenomenon of personal hygiene, environmental sanitation and skin health complaints in narapiadana in The Women's Correctional Institution Class IIA Medan.

\section{RESULTS AND DISCUSSIONS}

\section{Personal Hygiene}

Definition of personal hygiene. Personal hygiene comes from the Greek language which consists of personal words that are individual and hygiene is healthy. So personal hygiene is an act of maintaining one's hygiene and health for both physical and psychic well-being (Isro'in and Andarmoyo, 2012). Personal hygiene has several objectives according to Isro'in and Andarmoyo (2012) namely:

1. Improved health degrees

2. Maintenance of personal hygiene

3. Improving personal hygiene

4. Prevention of diseases

5. Creating beauty 6 . Increased confidence

Personal hygiene is part of the main human needs including individual health and hygiene in order to avoid disease. Skin hygiene is an act of maintaining individual hygiene such as bathing 2 times a day using soap to prevent infectious diseases (Tarwoto and Wartonah, 2003). Unhealthy living behaviors such as not washing your hands before or after eating, washing or bathing with dirty water are behaviors that can invite disease (Maharani, 2015). The results of research by Agsa Sajida (2012) have shown that skin hygiene has a significant association with skin disease complaints. 


\section{Theoretical Foundation}

The process of disease occurrence is the relationship of human behavior with environmental components that are potentially dangerous diseases, known as pathogenesis of disease. Pathogenesis of disease in the environmental perspective described in Knot Theory includes node 1 as the source of disease, node 2 is an environmental component that is a medium of transmission of disease, node 3 is a person with various population variables, node 4 is a person who is in a healthy or sick state after experiencing interactions with environmental components containing disease seedlings or disease agents, and node 5 is a set of suprasystem variables such as topography, climate or suprasystem policies such as politics and policy (Achmadi, 2017). Vertex 2 as an environmental component, vertex 3 as a variable of a person /individual and node 4 as the impact or condition caused, is a component that greatly affects the process of pathogenesis of disease.

\section{Individual Characteristics}

Age is a variable that is always considered because the number of pain and death almost all circumstances indicate a relationship with age (Purwoastuti, 2015). In the study, the average respondent was 26-45 years old and experienced skin health complaints. This is according to research by Aisha (2012), there is a meaningful relationship between age and complaints of skin disorders because complaints of skin disorders are more prone to occur in old age.

Changes in the skin begin to occur as a person ages even though they can be seen clearly or vaguely. As you get older there is a tendency of local hemorrhage as a result of minimal trauma due to the reduced quality of the skin and increased fragility of blood vessels, a decrease in the amount of melanocytes on the skin that can lead to a decrease in melanin production, a decrease in sebum production that causes the skin to become drier, and a decrease in the skin's ability to maintain water levels that cause severe itching of the skin (Maharani , 2015).

\section{Level of education}

Knowledgeable people will have more information when compared to the ignorant (Revika, 2019). The level of education can improve one's knowledge including about health. The higher the level of education a person has, the more aware of preventive measures against the transmission of skin diseases (Notoatmodjo, 2003).

\section{Detention period}

The results of the study found that the average respondent with a prison term of $\geq 3$ years and experienced skin health complaints as many as 49 people $(57.1 \%)$. This is according to research conducted by Asrul (2013) explaining that the longer in the prison, the more likely it is to contract skin diseases will be able to occur.

\section{Personal Hygiene}

Skin hygiene. Hygienic behavior can prevent skin diseases, namely bathing with clean water at least 2 times a day using soap (Budiman and Suyono, 2019). The results showed that most respondents showered twice a day $(69.8 \%)$ and use soap. A good and correct bath is the body cleaned with bath soap. Dirt and bacteria attached to the surface of the skin can be removed due to soapy froth. Then the body is washed with water until clean, the body is rubbed until all the dirt or daki comes out. Try to clean the daki from the face, legs and folds of the body and rubbed continuously by hand. Then the body is watered to the feet until completely clean (Irianto, 2007).

The research site is in The Women's Correctional Institution Class IIA Medan. Medan Women's Correctional Institution Class IIA was established in 1983-1985 on February 26, 1986 which is located at Tanjung Gusta Correctional Street Medan with a distance of about $5 \mathrm{~km}$ from the city center. The area of The Women's Correctional Institution Class IIA Medan is $6,455 \mathrm{~m} 2$ with a building area of $5,250 \mathrm{~m}^{2}$.

The results of the study obtained complaints of itchy skin as many as 49 respondents (57\%), and dry skin as many as 52 respondents $(60.5 \%)$. Dry skin occurs when the skin is deficient in lipids (fatty acids). Dry skin can produce a rough skin texture and the presence of red specks. Skin complaints felt rough as many as 48 respondents (55.8\%), complaints in the form of patches and reddish spots on the skin as many as 28 respondents (32.6\%). Complaints in the form of skin texture felt cracked as many as 22 respondents $(25.6 \%)$ and the surface of the skin was exfoliated by 24 respondents (27.9\%). Exfoliating skin can trigger wounds on the skin, this can damage the structure and anatomy of normal skin.

\section{CONCLUSION}

The majority of inmates aged 26-45 years $(53.5 \%)$, educated in elementary-junior high school /MTs (44.2\%) with a prison term of $\geq 3$ years $(65.1 \%)$. Inmates with skin health complaints aged 26-45 years $(47.7 \%)$ educated elementary-junior high school/MTs (38.4\%) with a prison term of $\geq 3$ 
years $(57.1 \%)$. The habit of skin hygiene in inmates belongs to the category of sufficient $(45.4 \%)$. The hygiene habits of hands, feet and nails in inmates fall into the category of adequate $(54.6 \%)$. Hair hygiene habits in inmates fall into the sufficient category $(47.6 \%)$. Conditions for wearing clothes in inmates fall into the sufficient category (44.2\%). Conditions for using towels in inmates fall into the sufficient category $(47.6 \%)$. The conditions for using beds and bed linen in inmates fall into the bad category $(50.0 \%)$. Environmental sanitation conditions are included in the qualifying criteria with a total score of 1,680. Inmates who experienced skin health complaints as many as 75 people (87.2\%). The most common types of skin health complaints experienced by inmates were dry skin $(60.5 \%)$, itchy skin $(57 \%)$, rough skin such as scaly $(55.8 \%)$, patches and reddish spots on the skin $(32.6 \%)$ and exfoliation on the surface of the skin (27.9\%).

\section{REFERENCES}

Achmadi, U.F. (2017). Manajemen penyakit berbasis wilayah. Jakarta: Rajawali Pers.

Afriani, B. (2017). Hubungan personal hygiene dan status sosial ekonomi dengan kejadian skabies di pondok pesantren. Jurnal Ilmu Kesehatan.

Aisyah, F. (2012). Hubungan higiene perorangan dan pemakaian alat pelindung diri dengan keluhan gangguan kulit pada pekerja pengupas udang di kelurahan pekan labuhan kecamatan medan labuhan tahun 2012. Medan: Universitas Sumatera Utara.

Aziz, A. H. (2009). Metode penelitian keperawatan dan teknik analisa data. Jakarta: Salemba Medika.

Djuanda, A. (2010). Scabies ilmu penyakit kulit dan kelamin. (Edisi Ke-5). Jakarta: Fakultas Kedokteran Universitas Indonesia.

Budiman., \& Suyono. (2019). Buku ajar epidemiologi kesehatan lingkungan. Bandung: PT Refika Aditama.

Eryando, T. (2017). Teori dan aplikasi pengumpulan data kesehatan. Yogyakarta: Rapha Publishing.

Frenki. (2011). Hubungan personal hygiene santri dengan kejadian penyakit kulit infeksi scabies dan tinjauan sanitasi lingkungan pondok pesantren darel hikmah kota pekanbaru. Jurnal universitas sumatera utara.

Irianto, K. (2007). Menguak dunia mikroorganisme. Bandung: CV Yrama Widya.

Isro'in, L., \& Andarmoyo, S. (2012). Personal hygiene. Yogyakarta: Graha Ilmu.

Kementerian Hukum dan Hak Asasi Manusia RI. (2009). Pedoman Penanganan Kesehatan Lingkungan di Lembaga Pemasyarakatan dan Rumah Tahanan Negara Kementerian Hukum dan HAM Direktorat Jenderal Pemasyarakatan Direktorat Bina Perawatan.

Kementerian Hukum dan Hak Asasi Manusia RI. (2019). Data Laporan Lembaga Pemasyarakatan Perempuan Kelas IIA Medan tahun 2019. Medan: Anonim.

Kementerian Kesehatan RI. (2010). Profil Kesehatan Indonesia Tahun 2009.
Keputusan Menteri Kesehatan RI. No. 829/Menkes/SK/VII/1999 tentang Persyaratan Rumah Sehat.

Lita, S. (2005). Perilaku santri dalam upaya pencegahan penyakit skabies di pondok pesantren ulumu qur'an stabat. Jurnal universitas sumatera utara.

Maharani, A. (2015). Penyakit kulit, perawatan, pencegahan dan pengobatan. Yogyakarta: Pustaka Baru Press.

Notoatmodjo, S. (2003). Ilmu kesehatan masyarakat prinsip-prinsip dasar. Jakarta: PT Rineka Cipta.

Notoatmodjo, S. (2011). Kesehatan masyarakat ilmu dan seni. Jakarta: PT Rineka Cipta.

Pasaribu, A. (2013). Hubungan sanitasi lingkungan dan higiene perseorangan dengan kejadian scabies di rutan cabang sibuhuan kabupaten padang lawas tahun 2013. Jurnal universitas sumatera utara.

Peraturan Menteri Hukum dan Hak Asasi Manusia RI No.11 Tahun 2017 tentang Grand Design Penanganan Overcrowded Pada Rumah Tahanan Negara dan Lembaga Pemasyarakatan.

Perry, P. (2005). Buku ajar fundamental keperawatan. Jakarta: EGC.

Purwoastuti, E., \& Walyani, E. (2015). Ilmu kesehatan masyarakat. Yogyakarta: PT Pustaka Baru.

Rismaninggar, K. (2009). Hubungan antara kepadatan hunian dan kualitas lingkungan fisik lembaga pemasyarakatan dengan keluhan penghuni lembaga pemasyarakatan kelas iia di sidoarjo. Jurnal Fakultas Kesehatan Masyarakat Universitas Airlangga.

Sajida, A. (2012). Hubungan personal hygiene dan sanitasi lingkungan dengan keluhan penyakit kulit di kelurahan denai kecamatan medan denai kota medan tahun 2012. Jurnal universitas sumatera utara.

Santoso, I. (2019). Inspeksi sanitasi tempat-tempat umum. Surabaya: Gosyen Publishing.

Sucipto, C. (2019). Kesehatan lingkungan. Yogyakarta: Gosyen Publishing. 